\title{
Theoretical approaches to determining the economic sustainability of enterprises
}

\author{
Vasilii Zhdanov ${ }^{1,}$, Lubov Vinnichek ${ }^{2}$, Maria Vizirskaya $^{3}$, and Ivan Zhdanov ${ }^{1}$ \\ ${ }^{1}$ Business school of Russian State University for Humanities, Miusskaya sq. 6, Moscow, 125993 , \\ Russia \\ ${ }^{2}$ Penza State Agricultural Academy, Botanicheskaya st. 30, Penza, 440014, Russia \\ ${ }^{3}$ All-Russian Research Institute of Agricultural Chemistry named after D.N. Pryanishnikova, \\ Pryaniishnikova st, 31, Moscow, 127550, Russia
}

\begin{abstract}
The article discusses various interpretations of the concept of economic sustainability of an enterprise by various Russian and foreign scientists. Features of the content of the concept of sustainability for economic and technical systems.
\end{abstract}

The terms "sustainability" and "sustainable" are often used in various fields of knowledge. There are four main meanings of the term "sustainability" in the Russian dictionary [1]:

- it is the ability to stand firmly and to hold on without hesitation or falling;

- it is the ability of an object to remain unchanged for a long time and to maintain its properties, state or/and position;

- it is the ability to resist any influence and not to undergo changes and fluctuations;

- it is the ability to resist external influences.

In particular, the "Soviet Encyclopedia" [2] says that if there is a characteristic of the system that is being influenced by insignificant initial distorting factors and that is maintaining its value throughout the subsequent time, provided that this value differs little from the value this characteristic should have while being in a state without any external influences, than the movement of the system in relation to this characteristic is called sustainable.

Encyclopedia of Mathematics does not contain a clearly defined interpretation of the term "sustainability". There is only a definition of sustainability in relation to tangible and intangible objects which depend on certain parameters. So, sustainability in relation to geometric and other objects is considered as "continuous dependence of these objects on parameters" [3].

This definition is widely used in natural Sciences to describe the functioning of technical systems. In physics, a theory of sustainability has been developed to study the oscillations of complex systems. There are various directions in the study of sustainability - sustainability of motion, sustainability of equilibrium state.

* Corresponding author: vasilii.zhdanov@gmail.com 
For a more complete understanding of the subject of "economic sustainability", we will reveal the essence of the concept "sustainability" in technical and economic systems.

The modern theory of sustainability was formed on the basis of the works of such scientists as J. Lagrange, A.M. Lyapunov, S.D. Poincaré, A. Poisson and others who were dedicated to researching the sustainability of systems. The results of their research are in the field of studying the equilibrium state of mechanical systems $[4,5,6]$.

- S.D. Poincaré and A. Poisson argued that the mechanical system is considered stable if it seeks to return to its original equilibrium state infinitely often after losing the balance under the influence of external factors.

- According to A.M. Lyapunov, sustainability is the ability of the system to remain its state which is very close to its original state despite the impact of external factors. In other words, sustainability is an ability to maintain the trend of its development.

- According to J. Lagrange, sustainability implies the ability of the system not to go beyond a certain area (trajectory).

We shall now analyze the definitions of the concept of "sustainability" in the researches of well-known economics scientists:

1. A. Wald, L. Walras, P. Samuelson, J.R. Hicks et al first considered sustainability in relation to economic systems. They achieved the first results in the field of sustainability when they conducted a study of market equilibrium and the conditions for achieving it [7].

2. A.A. Bogdanov, L.I. Evenko, T. Parson, V.S. Rappoport et al are the founders of the general theory of organization. Their achievements include the following:

a. they clarified the distinction between economic and financial sustainability;

they have proven the link between efficiency of enterprises functioning and sustainability;

b. they have proven that sustainability and economic development are the most important characteristics of the economic system;

c. they have proven that the socio-economic systems cannot be assessed by analogy with technical systems which are not that complicated.

3. G.P. Bystray, O.M. Belotserkovsky, I.R. Prigogine, G. Hagen et al are the scientists whose works were used as a basis for the formation of synergetics as a science that studies the spontaneous appearance and self-maintenance of ordered temporal structures and disordered structures in open nonlinear systems of various nature $[8$, 9, 10]. Their achievements include the following:

a. they have gotten the scientific justification of the fact that sustainability is a key driver of system dynamics (sustainability is a dynamic category);

b. they have proven that enterprises are the nonequilibrium system which moves either towards the equilibrium state or away from it at each moment of time.

It should be noted that exploring the sustainability of complex technical and economic systems has been carried out for a long time. But there is still no well-established generally accepted approach to the definition of this concept. And therefore, it is not possible to fully solve the problems of ensuring economic sustainability.

The term "sustainability", in fact, has no meaning, as it is relative. The stability of the system makes sense only in the comparison of the properties of the system with other systems. Same system is characterized by different sustainability indicators in relation to 
different systems. Thus, stability is a relative characteristic of the system which can only be evaluated in comparison with its past states or with another system.

It can be noted that the term "sustainability" has shifted from the technical field of knowledge to the economic sphere in these latter days. Now this characteristic of the system is applied to economic systems of different levels (economic system at the level of the whole world, national economic system and the economic system of an individual enterprise). One of the main features of these systems is their functioning in a dynamic external environment under the influence of various factors. This feature determines the complex nature of the functioning and management of these systems.

Russian economists began researching sustainability not so long ago. The most interesting definitions (in our opinion) are given in Table 1.

Table 1. How the term "enterprise sustainability" is interpreted by various authors

\begin{tabular}{|l|l|}
\hline \multicolumn{1}{|c|}{ Author } & \multicolumn{1}{c|}{ Interpretation of the term } \\
\hline $\begin{array}{l}\text { Benediktov } \\
\text { M.A. [11] }\end{array}$ & $\begin{array}{l}\text { The sustainability of the enterprise is the financial and economic state of the } \\
\text { enterprise, the economic activity of which, in normal conditions, ensures the } \\
\text { fulfillment of all its obligations to employees, to other enterprises and to } \\
\text { government due to sufficient income and to the fact that expenses correspond to } \\
\text { income. }\end{array}$ \\
\hline $\begin{array}{l}\text { Dmitriev A.M. } \\
{[12]}\end{array}$ & $\begin{array}{l}\text { Sustainability is the ability of the system to maintain a normal state under the } \\
\text { influence of insignificant and mostly random changes in its activity. }\end{array}$ \\
\hline $\begin{array}{l}\text { Zharikov O.N. } \\
{[13]}\end{array}$ & $\begin{array}{l}\text { Sustainability is the ability of a system to return to a state of equilibrium after it } \\
\text { was under the influence of external excitations. }\end{array}$ \\
\hline $\begin{array}{l}\text { Zubanov N.V., } \\
\text { Pestikov S.V. } \\
\text { [14] }\end{array}$ & $\begin{array}{l}\text { Sustainability is the ability of a system which is operating according to a certain } \\
\text { algorithm to achieve the goal of functioning in a certain phase of development. }\end{array}$ \\
\hline Safin F.M. [15] & $\begin{array}{l}\text { The sustainability of an enterprise is the state of an object, which is considered } \\
\text { in relation to external influences on it. }\end{array}$ \\
\hline $\begin{array}{l}\text { Timofeev } \\
\text { R.A.[16] }\end{array}$ & $\begin{array}{l}\text { Sustainability is the ability of a system to maintain its state, behavior and } \\
\text { existence, despite a change in the external environment. }\end{array}$ \\
\hline
\end{tabular}

M.A. Benediktov proposes an approach to understanding the term "sustainability" based on taking into account the interests of the stakeholders of the enterprise. From our point of view, this approach is rather applicable when assessing the so-called "sustainable development of an enterprise" [17, 18], which involves meeting the interests of individual stakeholders - this subject is stated in the work of T.A. Pikalova, for example [19]. Nevertheless, we fully agree with the statement that economic sustainability is not limited to meeting the interests of the owners of the enterprise, and that the results of business activities are not limited to profit.

The approach of A.M. Dmitriev does not have sufficient specificity, since the term "normal state" of the enterprise is even more ambiguous than the term "economic sustainability". Moreover, the decision about which state of functioning of the enterprise is to be recognized as "normal" depends on the opinion of the enterprise's management and may vary with indefinite frequency - this fact makes it impossible to compare the sustainability indicator of an enterprise with indicators of sustainability of other enterprises and, which is more importantly, it does not allow to compare the current indicator of sustainability of an enterprise and the same indicator of this enterprise in past.

The approaches of N.V. Zubanov and S.V. Pestikov are related to the achievement of the set goals of the enterprise. In our opinion, this interpretation of the term is more consistent 
with the term of "effectiveness" which is defined as the indicator that demonstrates which part of the planned business activity has been implemented and what planned results were achieved (ISO 9000:2011) [20].

We shall now focus on the most significant differences between the terms "sustainability of the technical system" and "sustainability of the economic system".

Table 2. The difference in interpretation of the term "sustainability" in relation to economic and technical systems

\begin{tabular}{|c|c|c|}
\hline \multirow{2}{*}{$\begin{array}{l}\text { Parameters for the } \\
\text { interpretation of the term } \\
\text { "sustainability" }\end{array}$} & \multicolumn{2}{|r|}{ Systems } \\
\hline & Technical systems & Economic systems \\
\hline 1. The essence of the term & \multicolumn{2}{|c|}{$\begin{array}{c}\text { The ability of a system to return to (1)/(2) after being taken out of } \\
\text { equilibrium }\end{array}$} \\
\hline & (1) its original state & (2) a new equilibrium state \\
\hline $\begin{array}{l}\text { 2. The nature of the } \\
\text { equilibrium system }\end{array}$ & Static & Dynamic \\
\hline $\begin{array}{l}\text { 3. The role in the } \\
\text { development of the system }\end{array}$ & & $\begin{array}{l}\text { Development sustainability is the ability of } \\
\text { a system to move to a qualitatively new } \\
\text { level after being taken out of a state of } \\
\text { equilibrium. } \\
\text { Breaking down the old structure and } \\
\text { creating a new sustainable structure. }\end{array}$ \\
\hline
\end{tabular}

It should be noted that an important feature of "sustainability" in relation to an economic object is that it demonstrates the ability of the object to maintain its completeness as a system and to develop despite the external negative influence. The sustainability of technical systems usually means their ability of keeping the constancy of the basic parameters of activity.

In our opinion, the most promising approach is the approach of F. Safin, but there is no clear explanation into it of how to interpret the state of an object depending on the external influences.

Summarizing the above, the term "sustainability of an enterprise" can be interpreted in the following way: it is a relative dynamic characteristic which reflects the ability to counteract the influence of unfavorable influences by achieving the best possible result based on efficient use of resources.

We shall now move on to the definition of "economic sustainability". The analysis of scientific literature has shown that the interpretation of economic sustainability has several significant variations (Table 3).

Obviously, each of the mentioned approaches has its own strengths, but a critical analysis of all these approaches revealed a number of shortcomings. For example, the definition of M.A. Makarova partially contradicts itself. On the one hand, it implies stable profitability in the long term (in other words, it implies invariability of the profit-to-cost ratio) and on the other hand, it implies an increase in profits. However, in the realities of today, it is impossible to talk about such a development of enterprises, because the increasingly complex external environment will not allow the enterprise to maintain any indicator at one stable level. Nevertheless, we fully agree, both with the fact that profitability is a significant indicator of assessing the activities of enterprises, and with the fact that the economic sustainability of an enterprise is determined by its ability to maintain expanded reproduction. 
Table 3. The analysis of theoretical approaches to the definition of the term "economic sustainability"

\begin{tabular}{|l|l|}
\hline \multicolumn{1}{|c|}{ Author } & \multicolumn{1}{c|}{ The definition of the term } \\
\hline Makarova M.A. & $\begin{array}{l}\text { The economic sustainability of an enterprise is a balanced state of technical } \\
\text { and economic resources which ensures stable profitability and normal } \\
\text { conditions for the expanded reproduction based on long-term profit and capital } \\
\text { growth taking into account external and internal factors. }\end{array}$ \\
\hline $\begin{array}{l}\text { Romanova A.I. } \\
\text { [22] }\end{array}$ & $\begin{array}{l}\text { The economic sustainability is the ability of a production system which is } \\
\text { moving in time and space not to change the vector of its movement being } \\
\text { under different internal and external influences. }\end{array}$ \\
\hline Sokolov S.V. [23] & $\begin{array}{l}\text { The economic sustainability of an enterprise is the adaptability of the } \\
\text { enterprise to the changes that have already occurred or that are expected in the } \\
\text { future. }\end{array}$ \\
\hline Shevrina E.V. [24] & $\begin{array}{l}\text { Economic sustainability is the ability of an enterprise to maintain and increase } \\
\text { its own production potential over a relatively long period of time in order to } \\
\text { maintain and expand the market segment it occupies. }\end{array}$ \\
\hline Shubina K.D. [25] & $\begin{array}{l}\text { Economic sustainability is the ability of an enterprise to withstand the threat of } \\
\text { bankruptcy. }\end{array}$ \\
\hline
\end{tabular}

From the point of view of E.V. Shevrina, economic sustainability is determined by the ability to maintain and build capacity. The author believes that this approach is promising, but an enterprise which has a significant accumulated potential in a particular sphere may annually deteriorate its production performance due to ineffective use of this potential. But in our opinion, the issue of maintaining and expanding the market relates primarily to the field of competitiveness management which does not allow to fully interpret the term "economic sustainability" despite the significant dependence of enterprises on market trends.

The opinion that economic sustainability implies the ability to withstand the threat of bankruptcy is quite justified, but only if we equate economic and financial sustainability.

The approaches of A.I. Romanova and S.V. Sokolov can be considered interesting. However, if we choose the first approach, it becomes difficult to understand the meaning of the term "movement of the production system". Specifically, we don't have an answer on the question of which movement will be considered acceptable and from whose point of view. The second approach uses the term "adaptability" which has a similar semantic meaning to the term "sustainability". But the term "adaptability" mostly means the ability of an enterprise to be flexible to changes in the external environment [26], while the term "economic sustainability" takes into account the internal state of enterprise too.

\section{Conclusion}

Based on the analysis results, it can be concluded that the main characteristic of economic sustainability should be the maintenance of a certain state of the enterprise which will allow to support expanded reproduction expressed in the growth of the main indicators of its activities, such as profit. In other words, each of the considered approaches suggests focusing on certain aspects of economic growth which, according to S.V. Fedoseev, is the main goal of the enterprise development, and this goal involves improving economic results and reducing costs both by involving additional production resources (extensive factors) and by increasing the efficiency of their use (intensive factors) [27]. 
Summarizing the above, it can be argued that the term "economic sustainability of an enterprise" means the ability of an enterprise to maintain productivity at a level that allows it to achieve economic growth despite any unfavorable influences.

\section{References}

1 RAS, Institute of linguistics, ed.: Evgenieva A.P. Slovar' russkogo yazyka [Dictionary of the Russian language: in 4 v.], Moscow, Poligrafresursy Publ., 1999. 797 p.

2 Ed.: Vvedenskij B.A. Sovetskaya entsiklopediya [Soviet encyclopedia], 1985. 776 p.

3 Ed.: Vinogradov I.M. Matematicheskaya entsiklopediya [Encyclopedia of Mathematics], Sovetskaya entsiklopediya Publ., 1985. 776 p.

4 Lyapunov A.M. Obshchaya zadacha ob ustoychivosti dvizheniya [General problem of motion stability], sobstvennye sochineniya $v 6$ tomah [Lyapunov's own works in 6 v.], AN SSS Publ., 1956. 473 p.

5 Poincaré A. Favorite works in 3 v., 1991-1994. 771 p. (Russ. ed.: Puankare A. Izbrannye trudy v 3 tomah. Moscow, Nauka Publ., 1991-1994. 771 p.).

6 Smale S. Differenciruemye dinamicheskie sistemy [Differentiable dynamic systems], Uspekhi matematicheskih nauk [Advances in Mathematical Sciences], 1970, V.25, I.1. pp. 113-185

7 Chuprov S.V. Razvitie nauchnyh vozzreniy ob ustoychivosti ekonomicheskih sistem v istoricheskoy retrospektive [Development of scientific views on the stability of economic systems in historical retrospective], Chuprov S.V. Istorikoekonomicheskie issledovaniya [Historical and Economic Research], 2013, V. 14, no. 1-2. pp. 15-32

8 Belocerkovskij O.M., Bystray G.P., Cibul'skiy V.R. Ekonomicheskaya sinergetika: voprosy ustoychivost [Economic Synergy: Issues of Sustainability], Novosibirsk: Nauka, 2006. 116 p.

9 Prigozhin I., Stengers I. Order out of chaos: A new dialogue between man and nature (Russ ed.: Prigozhin I., Stengers I. Poryadok iz haosa: Noviy dialog cheloveka s prirodoy, ed.: Arshinov V.I., Klimontovich Yu.L., Sachkov Yu.V., Progress Publ., 1986. 432 p.)

10 Khaken G.Informaciya i samoorganizaciya [Information and self-organization], Mir Publ., 1991. 240 p.

11 Bendikov M.A., Nikonova A.A. Methodological foundations for assessing the economic sustainability of an industrial enterprise. Konsul'tant direktora [Director's consultant], 2005, no.14(242), pp. 28-32

12 Dmitriev A. M. Razvitie metodov ocenki ekonomicheskogo sostoyaniya predpriyatiya $v$ usloviyah antikrizisnogo upravleniya [Development of methods for assessing the economic state of an enterprise in the context of anti-crisis management], Synopsis ... Ph.D., Nizhniy-Novgorod, 1999. 150 p.

13 Zharikov O.N. Korolevskaya V.I. Hohlov S.N. Sistemnyj podhod $k$ upravleniyu: Uchebnoe Posobie dlya vuzov [A Systems Approach to Management: Textbook for universities], YUNITI-DANA Publ., 2001. 62 p.

14 Zubanov N.V., Pestikov S.V. Analysis of the stability of the functioning of economic systems in relation to the goals set. Available at: https://www.sstu.samara.ru/ (Accessed 18 August 2011).

15 Safin F. Essence and factors of economic sustainability (problem statement). Available at: https://www.tisbi.ru/ (Accessed 9 June 2014)

16 Timofeev P.A. Ocenka ekonomicheskoj nadezhnosti predpriyatiya na osnove racional'nogo upravleniya toplivno-energeticheskimi resursami [Assessment of the 
economic reliability of the enterprise based on the rational management of fuel and energy resources], Dissertation ... Ph.D.: 08.00.05, Nizhniy-Novgorod, RGB Publ., 2006. 22 p.

17 Altushkin I.A., Korol' Yu.A., Cherepovitsyn A.E. Methodological approaches to the economic assessment of the sustainable development of a mining and metallurgical holding. Cvetnye metally [Non-ferrous metals], 2013, no.11, pp. 8-16

18 Altushkin I.A., Korol' Yu.A., Cherepovitsyn A.E. Methodological approaches to the economic assessment of the sustainable development of a mining and metallurgical holding. Cvetnye metally [Non-ferrous metals], 2013, no.11, pp. 8-16

19 Pikalova T.A. Upravlenie operatsionnoj deyatel'nost'yu gornoy kompanii na osnove kontsepcii korporativnogo ustoychivogo razvitiya [Operations management of a mining company based on the concept of corporate sustainability], Dissertation synopsis ... Ph.D., Saint Petersburg, 2014. 24 p

20 National standard of the Russian Federation GOST ISO 9000-2011 "Quality management systems. Fundamentals and vocabulary". Available at: http://files.stroyinf.ru/Data2/1/4293792/4293792471.htm (Accessed 3 April 2014)

21 Makarova M.A. Factors of economic sustainability of an oil company. Marketing [Marketing], 2004, no.3(76), pp. 93-97

22 Romanova A.I. Economic sustainability of the enterprise: problem statement. Izvestiya vuzov: Stroitel'stvo [News of universities: Construction], 2002, no.7, pp. 62-72

23 Sokolov S.V. Sovershenstvovanie mekhanizma ustoychivogo razvitiya ekonomiki predpriyatiya (na primere gornogo mashinostroeniya) [Improving the mechanism of sustainable development of the enterprise's economy (on the example of the mining engineering)], Dissertation synopsis ... Ph.D., Ekaterinburg, 2002, 24 p

24 Shevrina E.V. Ocenka ekonomicheskoy ustoychivosti sel'skohozyajstvennyh predpriyatiy (na primere Orenburgskoy oblasti) [Assessment of the economic sustainability of agricultural enterprises (on the example of the Orenburg region)], Dissertation synopsis ... Ph.D., Chelyabinsk, 2000. 23 p.

25 Shubina K.D. Assessment of the impact of the restructuring of the natural monopoly on the factors of economic sustainability of FAO "ACEC". Vestnik AmGU [The Messenger of Amur State University], 2007, no.39. pp. 105-108

26 Kuprin A.A. The main factors influencing the adaptability of enterprise management systems. Problemy sovremennoy ekonomiki [Problems of the modern economy], 2010, no.4. Available at: http://cyberleninka.ru/article/n/osnovnyefaktory-vliyaniya-naadaptivnost-sistem-upravleniya-predpriyatiem (Accessed 1 April 2014).

27 Fedoseev S.V. Strategicheskiy potentsial bazovyh otrasley promyshlennosti: monografiya [Strategic potential of basic industries: monograph], The Russian Academy of Sciences, Kol. Science Center, Institute for Economic Problems, Ministry of Education of the Russian Federation, Saint Petersburg State Polytechnic University, Saint Petersburg, KSC RAS, 2003. 268 p. 